\title{
特定セッション III「パッシブターゲティング」
}

2B1 2B15

\author{
オーガナイザー 高倉 喜信 (京都大院・薬) \\ 丸山一雄 (帝京大·薬) \\ 横山 昌幸（東京女子医大·医工研）
}

バッシブターゲティングは、薬物キャリヤーの体内動悊がその物理的、化学的性質と生体側の 解剖学的、生理学的特性とのハランスで規定される現象をうまく利用して莱物を病果局所に選択 的に送達するアプローチである。標的を特翼的に認識する抗体の利用などに代表されるアクティ ブターゲティングに比ベて、一般にその有用性に対する認識は低くなりがちではあるか、最近で は実用性に優れた種々の有望なシステムが開発され、臨床応用も活発に進められている。さら

に、本アブローチの発展はアクティブターゲティングの実現にも不可欠であり、D D S 研究にお ける重要な課題と考えられる。

本セッションでは、バッシブターゲティングに関する最新の情報交換を行い、研究・開器の将 来像を探ることを目的とする。キャリヤ一設計や基潄研究における適切な評価法、臨床応用の方 向性や䒠用化に向けての課題などについて総合的に討諭する。前半 (午前中) は、種々のキャリ ヤーシステムを用いた最近の成果が報告され、後半 (午後) はバッシブターゲティンクの標的と なりうる生体現象、各種治療への応用に主に焦点を当てた発表が予定されている。

十分な討論時間を用意しているので、フロアからも活発な討論を期待したい。

\section{B1}

水溶性高分子Bioconjugationによる生理活性蛋白質の分子レヘルでのDDS戦格

堤 康央、金田喜久, 角田慎一、鎌田春彦、牟 宇、 山本陽子、小平浩史、石川智世至、真弓忠範（阪大院・楽）

近年、サイトカインなどの生理活性蛋白質を次世代医薬品として適用しようとする武みが注目 されている。しかし一般に、生理活性蛋白質は体内安定性にそしいうえ、多様な in vivo 生理作 用を有するため、その臨床応用は著しく制限されてしまっている。従って有用性・安全性が確保 された次世代治癔薬として生理活性蛋白質を創出していくためには、体内安定性を向上させ得る 適切なDDSの開発とともに、多檬な in vivo 生理作用の中から目的とする治癔作用と副作用とを 選択分離し得る創薬技術の開拓が急務となっている。以上の観点から我々は、生理活性蛋白質の 水溶性高分子Bioconjugationを試みるとともに、その分子設計戦略の搆築を目差している。その 結果、治瘘目的や作用機满を考慮した最適条件でTNF- $\alpha$ やIL-6などをBiocojugationすることに より、体内安定性を飛躍的に向上できること、作用の選択性を付与し得ることなどが明らかとな つた。現在さらなる有用性・安全性確保の親点から、生理活性蛋白質の治療効果を高め得る付加 機能䕗入型修飾高分子や生体内举動制卸型修飾高分子の開発など、次世代Bioconjugationを確立 しようとしている。 


\section{B2}

配位結合を利用した水溶性高分子のタンパク質薬物への結合

○田烟泰应、野田幸腩、筏 券人

(京都大学生体医療工学研究センター)

タンバク質薬物の生体内不安定性を改善する一つの方法として、水溶性高分子による化学修 飾がある。しかしながら、化学反応にともなうタンぶク質の失活および操作の煩雜さが問题で あった。本研究では、金属配位結合を利用した薬物の修飾法を泼告する。一つの例として、睡

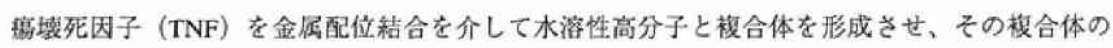
体内動態と抗がん作用を調べた。

铜イオンの存在下、キレート残基をもつデキストランと混合することによって、TNFの分子 サイズが増加し、TNFとデキストランとの間で䙡合体が形成することを液体クロマトグラフィ

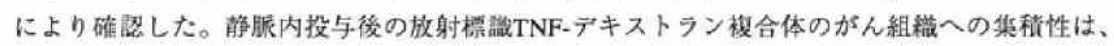
遊離TNFに比較して、集積量および带留性の点で優れていた。担がんマウスの静脈内へTNF-デ キストラン複合体を投与したところ、遊離TNFに比䡈して、より少ないTNF投与量でがんの増 殖を有意に㧕制した。以上の結果より、金属配位結合法は、単に、薬物と高分子とを混合する だけで两者が結合できる新しい楽物修飾法であることがわかった。

\section{B3}

キレート型配位結合を介してシスプラチンをデキストランに担持した 高分子ブロドラッグのパッシブターゲティングによる制癌活性

関西大工"、長崎大医 · 第二外科 ${ }^{21} 、$ 長崎大医 · 藥剂部 ${ }^{31}$

○大矢 裕- ${ }^{1} 、$ 益永 達則" 一瀨 浩郎 ${ }^{21} 、$ 中鸠 幹郎 ${ }^{31} 、$ 市川正孝 ${ }^{31} 、$ 兼松 隆之 ${ }^{21}$

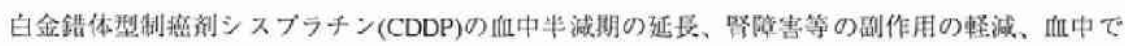

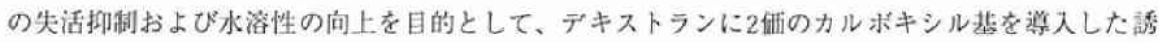
導体（ジカルボキシメチルデキストラン:DCM-Dex）にCDDPをキレート型配位結合で担持したコン

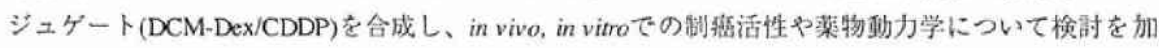
えた。In vitroにおけるコンジュゲートの細胞猝害活性をColon 26マウス大脇がん細胞に対して調心゙

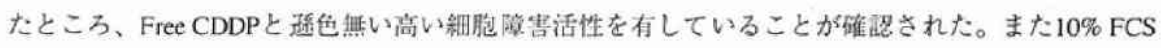

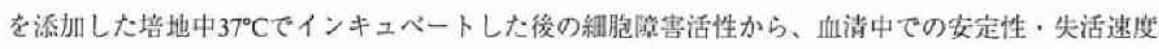
を䃑価したところ、コンジュゲート化により血清中での安完性が著しく向上することが示睃され た。ウイスターラットを用いた静注後のコンジュゲートの車中動態の解析結果からコンジュゲー 卜は、Free CDDPに比くて15倍以上も长い血中半隇期を有しており、さらにColon 26担嵒Balb/cマウ

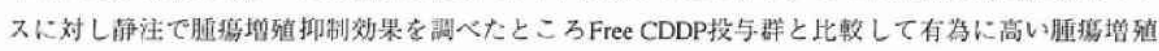
抑制効果を示したことから、高分子化によるバッシブターゲティンクの効果が示晙された。 
2B4

局所及び全身治癔を目的としたAdriamycin含有りボソーム

腹腔内投与の有効性に関する研究

○佐淥 秦之、広田 真雄

(静岡県大·薬)

【目的】制癌削の drug carrier としてのリボンームは広く模討されているが、そ

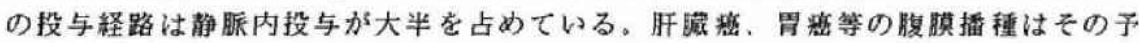
後を黑化させる要因であるが有効な治康法は磪立されていない。そこで、局所及ひ 全身治療を目的としてadriamycin (ADR) 含有リボソーム腹些内投与の有用性を检 討した。【方法】DMPC:DMPG:cholesterol:ADR よりなるリボソーム (PLADR) を調製し、これに超音波処理により PEG (Mw：2,000) を組み迈んたPEG-LADR

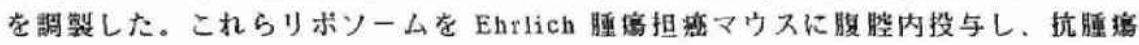
性、組䋨分布性、腹嘫内残存量を測定した。【結果及び考察】ADR 水溶液は、腹

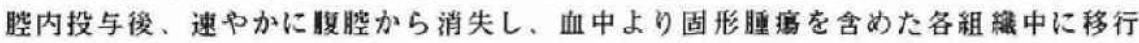
するが、PLADR やPEG-LADR は投与後8時間をかけて䌅やかに腹膛内より消失

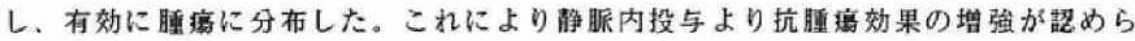
れ、リボソーム腹腔内投与が局所及び全身治療に有効である可能性が示咬された。

\section{B5}

ホリエチレングリコール（PEG）リボンームの運疾組織移行性と 腫瘁組繶内举動

○石田理 ${ }^{1}$ 、丸山一堆 ${ }^{1}$ 、岩鶴架治 ${ }^{1}$ 、佐々 木克典 ${ }^{2}$

(1 帝京大. 薬 2 山形大 ·医)

【目的】我々は、PEGリボソームが、その高い血中带留性と EPR 奻果によって、

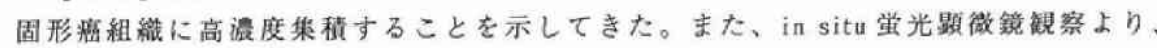
この集皘が、腫㜔租織血管内皮の不連続な部分からの漏出による可能性を示してき た。本研究では、PEGリボソームを用いた抗腫㹉菜物療法において重要な要素であ

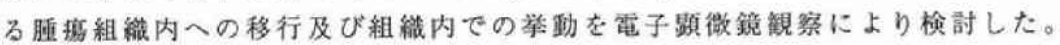

【結果及び考察】リボソームの腫揘組織内挙動を、 colon 26 皮下移植固形癁を用

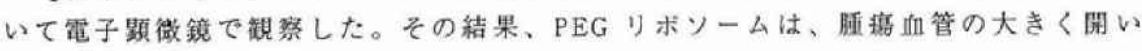
た内皮細胞間腺より漏出することが確悡された。また、腫場組織間質に漏出してき

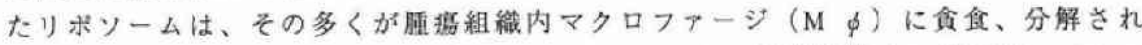

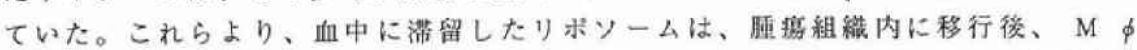

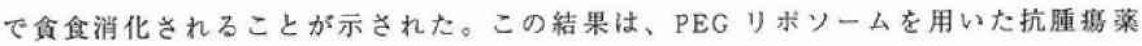

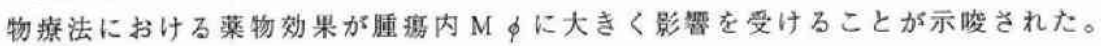




\section{B6}

$$
\text { トランスフェリン修饰PEGーリボソームによる }
$$

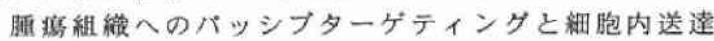

$$
\text { ○丸山一期 棚橋宏行 石田 理 岩鹤素治 }
$$

（帝京大・莱）

【目的】我々はこれまでに新生血管が発達しその脱透過性が亢進した固形嵒組織に対し て、血中滞留性の高いPEG-リボソームが比較的効率よく移行し集積することを報告して きた。一方、猫細胞表面にはトランスフェリン(TF)に対するレセブターが高頻度に発現 し、エンドサイトーシスで取り込まれることが知られている。本研究では、TFをPEG-リ

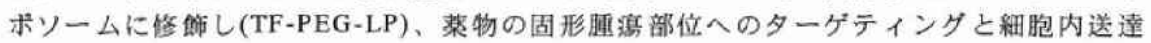
性について橹璟した。【方法】 DSPC/CH $(1: 1 \mathrm{~m} / \mathrm{m})$ の脂質組成にDSPE-PEG-COOHを添加 してリボソームを調製し、TFを反応させ、TF-PEG-LPを調製した。リボソームを蛍光ラ

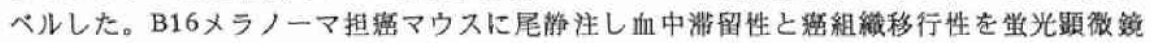

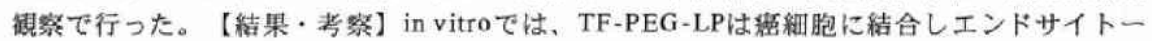

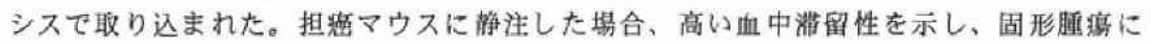

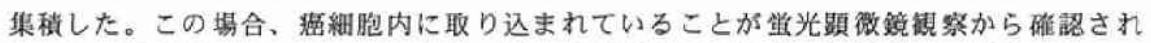
た。TF-PEG-LPのシステミックな投与は、内封物を固形近憱の細胞内まで送達できる可 能性を示した。

\section{B7}

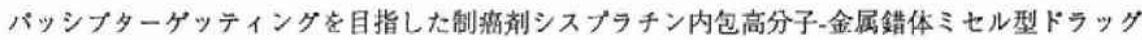
テリバリーシステム

○西山伸宏1、片岡一則 2 、

撗山昌幸 $3 、$ 青柳㦀夫 3 、岡野光夫 3 、櫻井靖久 ${ }^{3}$

(' 東理大 - 基碟工、 ${ }^{2}$ 東大 . 工、 ${ }^{3}$ 東女医大 · 医工研)

白金錯体制癌剂であるシスブラチン (CDDP) 臨床上で非常に有効な制㿋剂の一つであり、こ

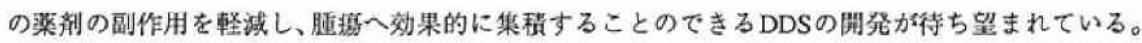
そこで本研究では、このCDDPとボリエチレングリコール・ボリアスバラギン酸フロック共重合体 が水中で錯形成することにより粒径約 $20 \mathrm{~nm}$ の高分子ミ七ルを形成することに着目し、その薬物担 体への可能性について検即を行った。实験結果より、CDDPを内包する高分子ミ七ルは水中に拈い ては完全に安定であるが、生理食塩水中においてはCDDPを徐放し、十数時間その形態を維持した 後ゆっくりと解離することが示唆された。また、この NaClに対する安定性はP (Asp) 鎖長により 制御できることが確認された。これらの結果より、この高分子ミセルは血流に打いては安定に循理 し腫境組織に集稓した後、薬物を放出する制御放出型のDDS となりうるものと考えられる。また in vitro 細胞素性評価により、製剂はミセルからの薬物のスローリリースにより薬効を発揮し、ミ セル内の薬物は全く失活していないことが示された。さらに in vivo制嵒活性評価により高分子ミ セルはフリーのCDDP以上の活性を示し、さらに薬物の有効治境漕度域の拡大が観察された。以上 の結果より、この高分子ミセルは固形秘治撩に有効なDDS 㹈剂となることか期待される。 


\section{B8}

疎水陮制痹凨KRN5500のミ七ル封入体の意義

○松村保広 ${ }^{1} 、$ 小池浩代 1 、小林暴子 ${ }^{1}$ 、坦添忠生 ${ }^{2}$ 、横山昌幸 ${ }^{3}$



('国立がんセンター・内科、" ${ }^{2}$ 国立がんセンター・院長、

東京女子医大・医用研、“東大·工)

【目的】蛋白合成阻害削KRN5500は、水に難楁で、種々の有機系溶媒に溶解後、静注されてい る。しかしながらその有機浴媒によると思われる血管炎なとの有害事象が悐められている。我々 はKRN5500をミセル封入させ有栱溶媒を用いることなく静注しうる剂型を作製した。今回ミセル 封入体の薬効、毒性について检討した。【方法】KRN5500およびそのミセル封入体（KRN/m)の 各種ヒト細胞株での活性はMTT assayによった。また $1 \times 10^{6}$ 個のヒト大腸趋株HT-29をヌードマウ

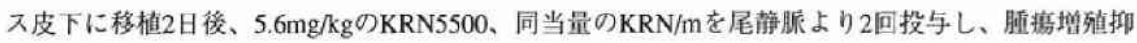
制効果およびマウスの体重变化を锶察した。毒性試験として、両薬剂の静注後1日、2䢙後の主要 楅器の病理学的检討およひ3日後の血液生化学的検討を行った。【結果】 in vitro, in vivoにおける抗

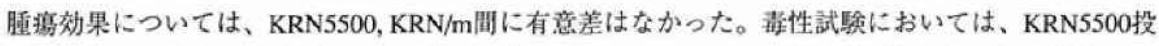
与群において有意な体重隇少、壊死性血管炎、肝focal necrords、また血液尿素空素の上界等認めた がKRN/m投与群では何ら異常を認めなかった。【結論】KRN/mはKRN5500の抗渪推効果を隇しる ことなく、KRN5500投与による種々の有害事象を克服し得るため、臨床上有用と考える。

\section{B9}

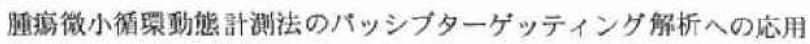

全身投与された高分子やリポソームが癌組織に集椯することが報告されてい る。この現象は、部分的には、腄㙞血管の透過性が充進していることが閣与す るパッシフターゲッティングの機構により生じると考えられている。現在、高 分子やリポソームをキャリアとして、抗癌郕を稳租機に集める試みがなされて

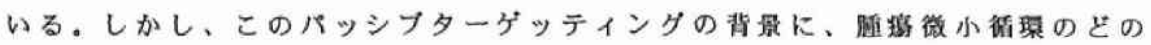
ような変化があるのかについての情報は十分ではない。高分子、リポりームの

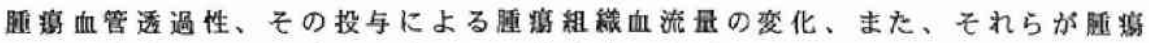
内に蓄積する経過など、多方面から㛟㷉する必要がある。我々はこれまでに、

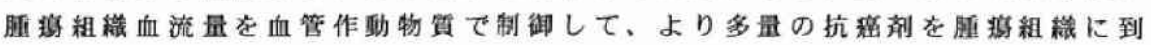
達させ、より長く停貿させることに成功している。本発表では、固形嵒への夕

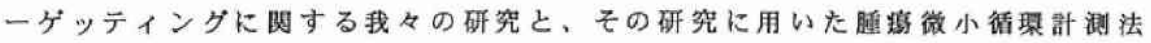
が、バッシブターゲッティングの解析に応用できることについて述へる。 


\title{
$2 \mathrm{~B} 10$
}

バーオキシナイトライト(ONOO)：腫庭血管透過性における役割と DDS への応用について

远 軍、○罯 智裕、赤池孝章、前田 浩

(能本大学・医·微生物)

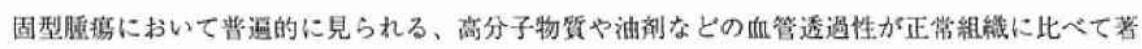

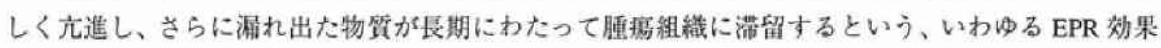

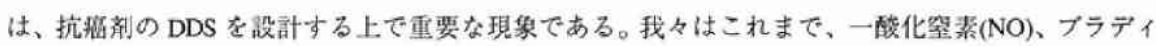
キニン、プロスタクラランジンがEPR 効果発現において重要な役割をしていることを明らかにした。 一方、ラジカル性の分子であるNOは、他の生体内ラジカルと速やかに反応し、中でもマクロファ

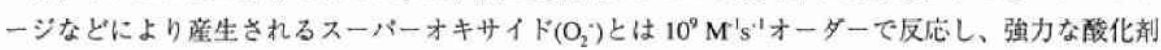

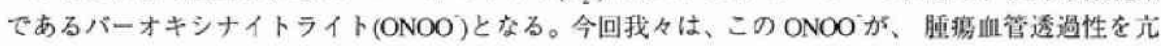
進させることを明らかにしたので報告する。色素（エパンスフルー、10 mg/kg）の集程から定量し た血管透過性は ONOO゙消去するエブセレン $(300 \mathrm{mg} / \mathrm{kg})$ や尿酸 $(500 \mathrm{mg} / \mathrm{kg})$ の投与により減少し、 ONOOが透過性光進因子として作用していることが示唆された。これら EPR 効果のメディエーター を制御することでより高度な腫瘏への DDS が達成されるものと考えられる。

\section{B11}

脳腫瘍の治療を目的とした制癌剤の新規脳内送達法

\author{
摄南大・薬○坂根稳康、新坦友隆、多喜陽子、 \\ 山下伸二, 瀬崎 仁 \\ 長崎大・医德永能治、柴田尚武
}

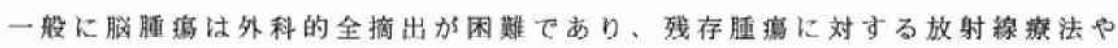

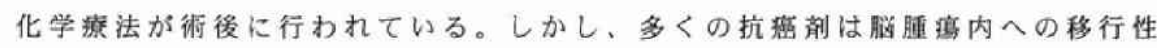
が低く、さらに、重篤な副作用が発現することが多いため、化学療法は有効と は言い難いのが現状である。したがって、脳腆癌に対する化学療法の有効性を 高めるためには、抗癌剛の畄腫瘍への送達勃率を高め、同時に全身的副作用の 柽減が可能な新しい投与法が必要と考えられる。我々は䀣に鼻腔内に投与され た薬物が譄春蹃液(CSF)人直接移行することを見い出し、薬物の脳内送達法と しての奥腔内投与の有用性を報告してきた。本研究では、鼻腔内に抗䆆剤を投 与し、CSFを介して脳腫癔に抗癌剤を送達するという新しい概念に基づいた新 規治療システムの開発を目指し、物理化学的性質の異なる 3 種類の抗窑剤の中 から有効な抗癌悄のスクリーニングを行うとともに、担癌モテル動物に対する 抗腱癔効果をin vivoにおいて測定し、本治療システムの有効性を倸価した。 


\section{B12}

インテリジェント ${ }^{10} \mathrm{~B}$ デリバリーシステムの中性子捕捉旗法への応用

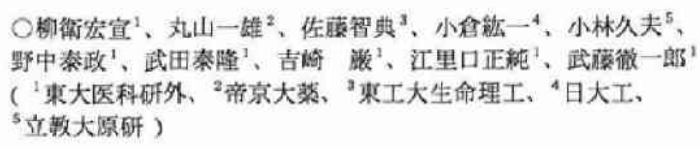

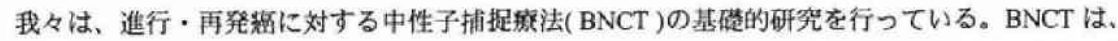

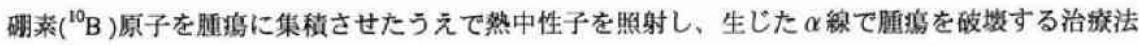
である。このため、いかに多くの ${ }^{10} \mathrm{~B}$ 原子を婳鹰に集槙させ得るかが重要なポイントとなって

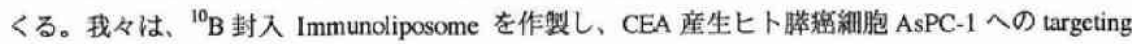

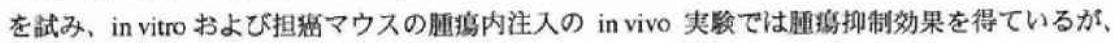
静注法では網内系に捕捉される可能性が強い。このため、Polyethylene glycol を結合した ${ }^{10} \mathrm{~B}$ 封入 Stealth liposome を AsPC-1 担稆マウスに静注し、中性子ラジオダラフィーを用いて集稓性を検捨し

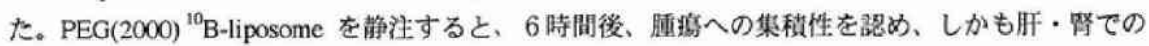

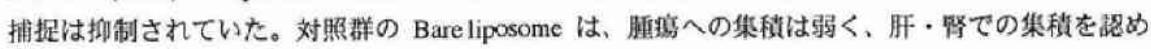
た。 1) Liposome を PEG 化することにより血中での滞留性を高め、2 ${ }^{10} \mathrm{~B}$ 化合物を重合し liposome

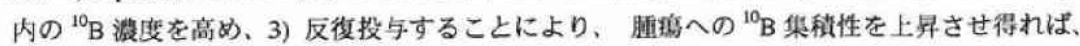
BNCT の効果增強が期待でき、早期の臨床応用が実現できると思われる。

\section{$2 \mathrm{~B} 13$}

生物由来磁気超微精子を用いるターゲティング材料の分子デザイン

松永是、田中剛、○中村德幸

(東京農工大·工・生命工)

近年、リボソームを利用したドラッダデリハリーが检討されているが、その效果 や安全性の面から特異的に黑部へ薬物等を送邀する方法が切望されている。本研究

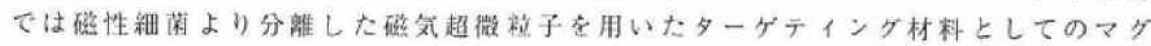
ネトリポソームのデザインとその応用について述へる。ホスファチジルコリン及び コレステロールを用いた逆相蒸発法の際に、磁気超微粒子を分散させることにより、 リボソームを調彆した。この結果、磁父応答する平均粒径 $300 \mathrm{~nm}$ のマダネトリポソー ムが電子䫓微鏡により䘽察された。さらに、春際にマウスに抗ガン剂シスプラチン (CDDP)を封入したマグネリポソームをドラッグキャリヤーとして注入し磁场に よる薬剂の集中固定について顿則した。各䑏器等でのシスブラチン由来の白金残留 量は原子吸光法によって測定し、薬剂固定効率を眮へた。その結果、CDDP封入マ グネトリポソーム老用いることで、磁石固定部位に多くの白金の残留が磪磂され、 以上のことから、外部磁場による薬剂の固定が可能であることが示された。 


\section{B14}

AZTリン脂質踒導体を封入した脂梊分散系製剂のリンパターゲティンク

○福澄正规 ${ }^{1}$, 传藤雅樹 '

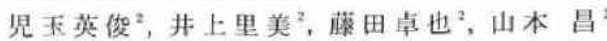

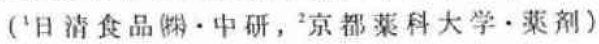

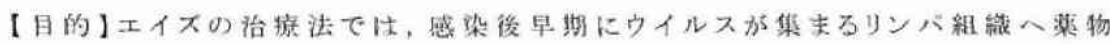



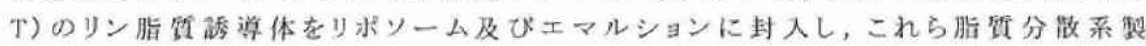

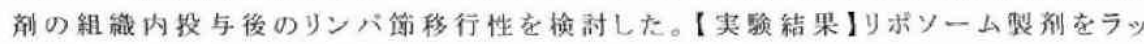

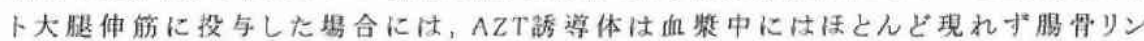
バ筇に長時問存在し、リンバ節内洔繶的にAZTを放出していることが確翟された。 この際のAUCは,AZT溶腹を筋注した量合に比バて有意に增大した。次にエマルシ ョン製剂をラット後肢足蹠皮下あるいは腹腔内に投与し，投与部位によるリンパ艒





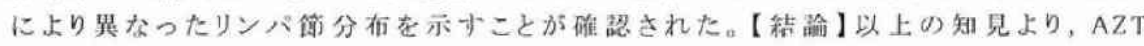

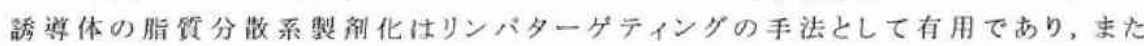

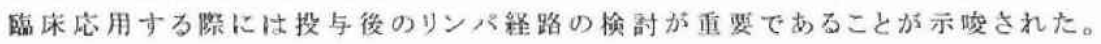

\section{B15}

経鼻インフルエンザウイルス蛋白質（あるいはブラスミド DNA）

ワクチンの關発に伴う問題点

国立感染症研究所感染病理部

田村傎一

我々は、IgG抗体を踒尊する現行の皮下接種インフルェンザウイルス蛋白質 ワクチンの予防効果を改善するために、ワクチンをアジュバント（微量のコレ ラトキシンを含むそのBサブユニット) と其に経奥免疫することを訊みてき


は多量体であるため、变異ウイルスとる交又反応する能力が高く、ワクチン株 と流行ウイルス株が異なる時にもインフルェンザを予防した。経䋰兔疫するこ とによって気道に IgA 抗体を梖䆃することの有用性は、ウイルス蛋白質ワクチ ンばかりでなく、プラスミト DNAワタチンを用いた場合にもあてはまる。こ れらワクチンの寒用化にむけて、つぎの二つの問題が提起される。(1) 蟫白 質ワクチンの使用に際しては、それ自身が抗体応答を锈導しない、毒性の少な いアジュパントを開発する。( 2 )ブラスミドDNAワクチンの使用に䄞しては、 粘膜の上皮細胞にブラスミドDNAが高率に澊入される方法を關発する。 